\title{
MANFAAT PENAMBAHAN TEPUNG KUNYIT (Curcuma domestica Val) DAN TEPUNG JAHE (Zingiber officinale) TERHADAP KUALITAS BAKSO ITIK AFKIR DENGAN LAMA PENYIMPANAN YANG BERBEDA
}

\section{THE ADVANTAGE OF TUMERIC FLOUR (Curcuma domestica Val) AND GINGER FLOUR (Zingiber officinale) ADDITION ON QUALITY OF CULLED DUCK MEATBALL IN DIFFERENT STORAGE TIMES}

\author{
Indah Nur Lestarini*, Novitasari Anggarawati, Adi Magna Patriadi Nuhriawangsa, dan \\ Ratih Dewanti \\ Jurusan Peternakan, Fakultas Pertanian, Universitas Sebelas Maret, Surakarta, 57126
}

Submitted: 25 August 2014, Accepted: 2 January 2015

\section{INTISARI}

\begin{abstract}
Penelitian bertujuan untuk mengetahui manfaat aras penambahan tepung kunyit dan tepung jahe dan waktu penyimpanan serta interaksi kedua faktor terhadap kualitas bakso itik afkir. Materi yang digunakan adalah daging itik afkir, tepung kunyit dan tepung jahe. Desain percobaan yang digunakan dalam penelitian adalah Rancangan Acak Lengkap pola faktorial $4 \times 3$ dengan faktor pertama aras penambahan tepung kunyit $(0 ; 0,5 ; 1 ; 1,5 \%)$ atau tepung jahe $(0 ; 1 ; 2 ; 3 \%)$, serta waktu penyimpanan $(0 ; 8 ; 16$ jam). Hasil penelitian menunjukkan lama penyimpanan berpengaruh nyata $(\mathrm{P}<0,05)$ terhadap $\mathrm{pH}$, keempukan, daya ikat air. Konsentrasi penambahan tepung kunyit dan tepung jahe berpengaruh nyata $(P<0,05)$ terhadap keempukan. Tidak terdapat interaksi antara kedua faktor terhadap $\mathrm{pH}$, daya ikat air, keempukan dan total bakteri proteolitik. Aras penambahan yang terbaik pada bakso itik afkir adalah $0,5 \%$ tepung kunyit dan $1 \%$ tepung jahe dengan waktu penyimpanan 0 jam, dengan nilai $\mathrm{pH} 6,49$, keempukan 0,31, daya ikat air 22,27, serta total bakteri proteolitik $3,57 \times 10^{4}$. Kesimpulan penelitian ini adalah aras penambahan yang terbaik adalah $0,5 \%$ tepung kunyit dan $1 \%$ tepung jahe dengan lama penyimpanan 0 jam karena dengan pemberian tepung kunyit dan tepung jahe belum bermanfaat terhadap bakso itik afkir.
\end{abstract}

(Kata kunci: Bakso, Itik afkir, Lama penyimpanan, Tepung jahe, Tepung kunyit)

ABSTRACT

The aim of the research was to determine the advantage of tumeric flour (Curcuma domestica Val) and ginger flour (Zingiber officinale) addition on quality of culled duck meatball in different storage times. The materials were thigh duck, tumeric flour and ginger flour. The design used in experiment was a Completely Randomized Design (CRD) with factorial pattern $4 \times 3$ as the first factor was concentration of turmeric flour $(0 ; 0.5 ; 1.0 ; 1.5 \%)$ and ginger flour $(0 ; 1 ; 2 ; 3 \%)$ and the second one was storage time $(0 ; 8$; 16 hours). The result of the research showed that storage time affected $(P<0.05) \mathrm{pH}$, tenderness and waterholding capacity. Concentration of tumeric flour and ginger flour affected tenderness. There was no interaction between those two factors on $\mathrm{pH}$, water-holding capacity, tenderness, and total proteolitic bacteria. Concentration of turmeric flour $0,5 \%$ and ginger flour $1 \%$ with storage time during 0 hours gave the best result, with a $\mathrm{pH}$ value 6.49 , tenderness 0.31 , water-holding capacity 22.27 , and a total proteolytic bacteria , $3.57 \times 10^{4}$. In conclusion, the finest result founded at $0.5 \%$ of turmeric flour and $1 \%$ of ginger flour addition in meatball before storage.

(Keywords: Culled duck, Ginger flour, Meatball, Storage time, Tumeric flour)

\section{Pendahuluan}

Bakso merupakan produk olahan yang disukai masyarakat, terbuat dari daging yang terlebih dahulu dihaluskan dan dicampur dengan pati dan bumbu lainnya, kemudian dibentuk bulat-bulat dengan tangan. Pada

\footnotetext{
* Korespondensi (corresponding author):

Telp. +62 85728212314

E-mail: novitasari_indahn@yahoo.com
}

awalnya bakso dibuat dari daging sapi namun sekarang juga dibuat dari daging ayam dan ikan (Purnomo dan Rahardian, 2008). Bakso merupakan produk olahan daging yang mudah rusak dan kualitas mikrobia produknya ditentukan oleh kualitas daging awal dan bahan lain, kebersihan pekerja yang menangani dan kemungkinan kontaminasi saat pengolahan (Elmali dan Yaman, 2005). Kandungan nutrien dan kadar air yang tinggi pada bakso menyebabkan bakso mempunyai 
masa simpan sampai 5 hari pada suhu refrigerate atau sekitar $5^{\circ} \mathrm{C}$ (Baygar et al., 2008). Bakso akan mengalami penurunan kualitas apabila terkontaminasi mikrobia, sehingga bakso daging itik menjadi rusak dan tidak layak konsumsi.

Itik afkir mempunyai nilai ekonomis yang rendah karena daging itik afkir berbau amis, warna kehitaman, teksturnya lebih alot, dan jumlah daging hanya sedikit (Rakhmadi et al., 2009). Nilai daya guna daging itik afkir bisa ditingkatkan dengan menjadikan salah satu alternatif bahan pengganti daging sapi pada bakso.

Kunyit merupakan tanaman herbal yang mengandung zat kurkumin dandapat memberikan warna pada produk hasil olahan. Kurkumin selain memberikan warna kuning, juga memiliki senyawa bioaktif yang berperan sebagai antimikrobia (Purwani et al., 2012). Senyawa kurkumin yang bekerja secara efektif dapat menghambat degradasi makromolekul melalui proses pemecahan protein menjadi molekul sederhana (seperti asam amino). Pemecahan inilah yang menyebabkan sel-sel membusuk disebabkan oleh metabolisme mikrobia, sehingga pembusukan sel tersebut dapat dihambat dengan menggunakan ekstrak kunyit, karena ekstrak kunyit dapat memperlambat metabolisme mikrobia (Sari, 2009).

Jahe merupakan rempah-rempah beraroma, mempunyai rasa pedas dan hangat, dan umumnya digunakan sebagai bahan penambah citarasa pada produk-produk seperti hasil ternak. Aroma khas jahe disebabkan oleh minyak atsiri. Jahe mengandung enzim proteolitik proteinase thio dan zingibain, yang dapat digunakan untuk mengempukan daging sebelum dimasak, sehingga sangat mempengaruhi kualitas fisik ( $\mathrm{pH}$, keempukan, dan susut masak) produk olahan dari daging (Rahardjo dan Rostiana, 2005).

Daging itik potensial untuk diolah menjadi produk seperti bakso. Berdasarkan hal tersebut, maka dilakukan penelitian dengan penambahan tepung kunyit dan tepung jahe dengan konsentrasi dan lama penyimpanan yang berbeda pada bakso itik afkir terhadap nilai $\mathrm{pH}$, keempukan, daya ikat air (DIA), dan total bakteri proteolitik. Pemberian tepung kunyit dan tepung jahe pada bakso itik diharapkan dapat meningkatkan kualitas serta memperlama penyimpanan.

\section{Materi dan Metode}

\section{Materi}

Materi yang digunakan dalam penelitian ini adalah $5 \mathrm{~kg}$ daging itik lokal betina afkir umur 58 minggu dari peternakan rakyat desa Pondok Grogol Sukoharjo. Tepung kunyit dari kunyit Curcuma domestica yang berjenis kunyit kuning, dan tepung jahe Zingiber officinale yang berjenis jahe gajah.

\section{Metode}

Rancangan percobaan yang digunakan pada penelitian ini menggunakan Rancangan Acak Lengkap (RAL) pola faktorial $4 \times 3$ dengan dua faktor. Faktor pertama adalah pemberian tepung kunyit + jahe $(0,0,5+1$, $0,1+2,1,5+3 \%)$. Faktor kedua adalah lama penyimpanan $(0,8$, dan 16 jam). Bila analisis variansi menunjukkan perbedaan yang nyata $(\mathrm{P}<0,05)$ maka dilanjutkan dengan uji wilayah berganda Duncan's New Multiple Range Test (Steel dan Torrie, 1995). Pembuatan bakso itik afkir menurut Ariansah (2008) pada penelitian ini dilakukan dengan langkahlangkah seperti pada Gambar 1.

Pengujian $\mathrm{pH}$ bakso menggunakan alat $\mathrm{pH}$ meter (AOAC, 1995). Pengujian keempukan menggunakan alat penetrometer (Ockerman, 1983). Pengujian daya ikat air menggunakan metode Hamm (Soeparno, 2005). Pengujian total bakteri proteolitik dengan metode hitungan cawan menggunakan media skim milk agar (SMA) (Fardiaz, 1993).

\section{Hasil dan Pembahasan}

\section{Kualitas fisik}

Hasil penelitian penggunaan tepung kunyit dan tepung jahe dalam bakso itik afkir dengan lama penyimpanan yang berbeda terhadap kualitas fisik disajikan pada Tabel 1.

Nilai pH. Penambahan tepung kunyit dan jahe tidak berpengaruh pada $\mathrm{pH}$. Penambahan sampai $1,5 \%$ tepung kunyit dan $3 \%$ tepung jahe (P3) belum menyebabkan perubahan $\mathrm{pH}$. Hal ini sesuai dengan penelitian Puspitasari et al. (2013) yang menyatakan bahwa penambahan pasta kunyit pada daging sampai konsentrasi $30 \%$ tidak berpengaruh nyata terhadap $\mathrm{pH}$. Hal ini dimungkinkan kandungan senyawa fenol yang terdapat pada tepung kunyit dan tepung jahe sampai dengan aras konsentrasi 1,5\% tepung kunyit dan 3\% tepung jahe belum mampu bekerja secara optimum, sehingga 
belum mempengaruhi $\mathrm{pH}$ bakso itik dalam penelitian. Nilai $\mathrm{pH}$ bakso itik afkir pada penelitian ini berkisar antara 6,41 sampai 6,45 . $\mathrm{pH}$ yang tinggi menyebabkan senyawa fenol kurang efektif bekerja (Naufalin et al., 2006). Hal ini menyebabkan nilai pH tetap stabil karena tidak ada perubahan keseimbangan ion hidrogen. Yadnya et al. (2010) menyatakan bahwa konsentrasi ion hidrogen yang lebih tinggi menghasilkan nilai $\mathrm{pH}$ yang lebih rendah, dengan demikian nilai $\mathrm{pH}$ dipengaruhi oleh jumlah ion hidrogen. Anggraeni (2005) menyatakan bahwa $\mathrm{pH}$ merupakan jumlah ion hidrogen.

Hasil penelitian menunjukan bahwa lama waktu penyimpanan berbeda nyata $(P<0,05)$ terhadap bakso itik afkir. Lama waktu penyimpanan menunjukkan penurunan nilai $\mathrm{pH}$. Hal ini sesuai dengan penelitian Putri et al. (2013) yang menyatakan bahwa faktor penyebab penurunan $\mathrm{pH}$ adalah waktu penyimpanan. Nilai $\mathrm{pH}$ pada lama waktu penyimpanan 8 jam belum mengalami penurunan, tetapi pada lama penyimpanan 16 jam mengalami penurunan. Penurunan nilai $\mathrm{pH}$ dalam penelitian ini disebabkan perubahan struktur protein atau denaturasi protein. Denaturasi protein menyebabkan protein memecah menjadi asam sederhana, asam amino dan basa-basa yang mudah menguap (Putri et al., 2013). Selain itu menurut Risnajati (2010) penurunan pH selama penyimpanan karena adanya proses glikolisis anaerobik yang akan menyebabkan makin rendahnya kapasitas mengikat air sehingga mempercepat cairan keluar dari dalam daging. Denaturasi dan glikolisis oleh mikrobia dengan berjalannya waktu akan menghasilkan air yang keluar dari bakso dan dengan adanya waktu penyimpanan akan menguap, sehingga menyebabkan penurunan $\mathrm{pH}$ yang tampak nyata pada waktu 16 jam. Nilai $\mathrm{pH}$ pada penelitian ini berkisar antara 6,25-6,54, hasil tersebut masih dalam kisaran normal pH bakso menurut SNI No.013818-1995 kisaran $\mathrm{pH}$ bakso antara 5-7 (Standar Nasional Indonesia, 1995). Bakso pada penelitian ini masih layak untuk dikonsumsi karena $\mathrm{pH}$ bakso masih pada kisaran normal.

Tidak terdapat interaksi antara lama waktu penyimpanan dengan penambahan tepung kunyit dan jahe terhadap $\mathrm{pH}$ bakso itik afkir. Hal ini diduga zat antimikrobia pada tepung kunyit dan tepung jahe belum efektif menghambat bakteri. Zat antimikrobia berperan dalam menghambat mikrobia yang dapat mempengaruhi $\mathrm{pH}$ dengan bertambahnya waktu selama penyimpanan. Kurang efektifnya zat antimikrobia menyebabkan aktivitas bakteri tetap berlangsung pada fase lag menuju fase logaritmik, sehingga produk hasil sisa metabolismenya tidak mempengaruhi nilai $\mathrm{pH}$ dengan bertambahnya waktu penyimpanan (Puspitasari, 2008).

Keempukan. Penambahan tepung kunyit dan tepung jahe menunjukkan perbedaan nyata $(P<0,05)$ terhadap keempukan bakso itik afkir. Nilai keempukan yang semakin tinggi menunjukkan bakso semakin keras. Perlakuan kontrol P1 (tepung kunyit $0,5 \%$ dan tepung jahe 1,0\%), P2 (tepung kunyit 0,1\% dan tepung jahe 2,0\%), dan P3 (tepung kunyit 1,5\% dan tepung jahe $3,0 \%$ ), tetapi $\mathrm{P} 1, \mathrm{P} 2$ dan P3 tidak berbeda nyata. Aras penambahan tepung kunyit dan tepung jahe dapat mengempukkan bakso itik afkir dibanding kontrol. Hal ini diduga pada bakso itik afkir merupakan adonan antara daging itik dengan campuran antara lain

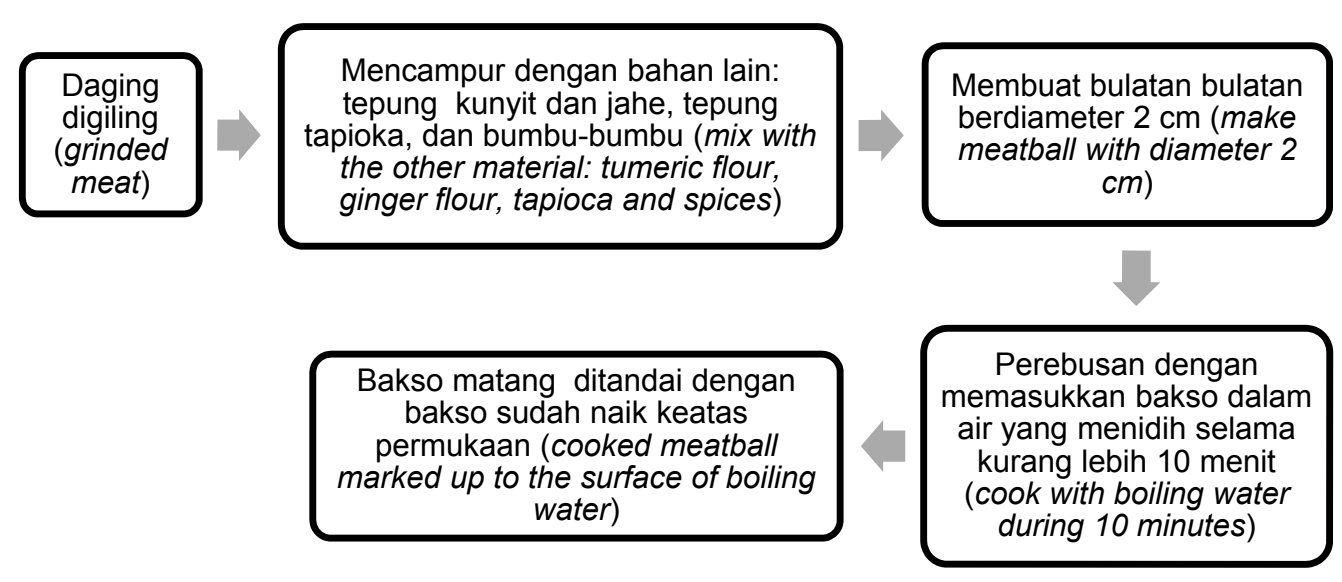

Gambar 1. Pembuatan bakso (procedure to make meatball). 
tepung pati sehingga menyebabkan protein pada daging yang terhidrolisis dapat membentuk emulsi cairan daging pada bakso. Emulsi terjadi karena adanya serat pada tepung kunyit dan jahe. Kandungan serat pada $100 \mathrm{~g}$ tepung kunyit berkisar $3,4 \%$ dan tepung jahe 2\% (Purwani et al., 2012). Kandungan serat yang menyebabkan kemampuan menyerap air tinggi. Penyerapan air oleh serat menyebabkan mikrostruktur bakso terbentuk rongga rongga karena adanya emulsi oleh serat. Soeparno (2005) menyatakan bahwa emulsi cairan daging yang terbentuk untuk mengisi mikrostruktur daging, sehingga bakso menjadi lebih empuk.

Hasil penelitian menunjukkan bahwa lama waktu penyimpanan bakso itik afkir 0 dan 8 jam berbeda nyata $(P<0,05)$ dengan lama penyimpanan 16 jam. Hasil penelitian menunjukkan terjadi kenaikan nilai keempukan setelah penyimpanan 16 jam, kenaikan nilai keempukan menunjukkan bakso semakin keras setelah penyimpanan
16 jam. Hal ini dimungkinkan terjadi penurunan kadar air sehingga dapat mempengaruhi keempukan bakso. Selama penyimpanan terjadi penurunan kadar air, sehingga menyebabkan mengkerutnya struktur protein daging dan tekstur menjadi lebih keras (Hadittama, 2009).

Interaksi antara lama waktu penyimpanan dengan penambahan tepung kunyit dan tepung jahe yang berbeda tidak berpengaruh nyata terhadap keempukan bakso itik afkir. Kandungan protease jahe diharapkan mampu menghidrolisis protein lebih cepat sehingga bakso lebih empuk, namun pada penelitian ini tidak demikian. Herdyastuti (2006) menyatakan bahwa faktor yang mempengaruhi kecepatan hidrolisis enzim adalah konsentrasi protease dan waktu inkubasi. Penelitian ini menunjukkan kombinasi konsentrasi enzim dan lama waktu simpan belum optimal, karena kecepatan enzim dengan konsentrasi P3 dalam menghidrolisis protein tidak seimbang sampai

Tabel 1. Rerata uji kualitas fisik (nilai pH, keempukan, daya ikat air) bakso itik afkir dengan aras penambahan tepung kunyit dan tepung jahe pada lama waktu penyimpanan yang berbeda

(the mean of physical quality test ( $\mathrm{pH}$, tenderness, water-holding capacity) of the culled duck meatball with turmeric powder and ginger powder addition in different storage time)

\begin{tabular}{|c|c|c|c|c|c|}
\hline \multirow{2}{*}{$\begin{array}{l}\text { Peubah yang diamati } \\
\text { (variable })\end{array}$} & \multirow{2}{*}{$\begin{array}{l}\text { Konsentrasi tepung kunyit dan } \\
\text { tepung jahe }(\%) \\
\text { (concentration of turmeric flour } \\
\text { and ginger flour }(\%) \text { ) }\end{array}$} & \multicolumn{3}{|c|}{$\begin{array}{l}\text { Lama waktu penyimpanan } \\
\text { (jam) (storage time (hours)) }\end{array}$} & \multirow{2}{*}{$\begin{array}{c}\text { Rerata } \\
\text { (average) }\end{array}$} \\
\hline & & 0 & 8 & 16 & \\
\hline \multirow[t]{4}{*}{ Nilai $\mathrm{pH}(\mathrm{pH}$ value $)$} & $0,0+0,0(\mathrm{P} 0)$ & 6,51 & 6,48 & 6,26 & 6,41 \\
\hline & $0,5+1,0(\mathrm{P} 1)$ & 6,53 & 6,46 & 6,25 & 6,41 \\
\hline & $0,1+2,0(P 2)$ & 6,55 & 6,5 & 6,23 & 6,42 \\
\hline & $1,5+3,0(P 3)$ & 6,56 & 6,53 & 6,26 & 6,45 \\
\hline Rerata (average) & & $6,54^{a}$ & $6,49^{a}$ & $6,25^{b}$ & \\
\hline \multirow[t]{4}{*}{ Keempukan (tenderness) } & $0,0+0,0(\mathrm{P} 0)$ & 0,33 & 0,36 & 0,43 & $0,37^{a}$ \\
\hline & $0,5+1,0(\mathrm{P} 1)$ & 0,3 & 0,28 & 0,33 & $0,3^{b}$ \\
\hline & $0,1+2,0(P 2)$ & 0,26 & 0,31 & 0,4 & $0,32^{\mathrm{b}}$ \\
\hline & $1,5+3,0(P 3)$ & 0,25 & 0,30 & 0,36 & $0,30^{\mathrm{b}}$ \\
\hline Rerata (average) & & $0,29^{b}$ & $0,31^{\mathrm{b}}$ & $0,38^{a}$ & \\
\hline \multirow{4}{*}{$\begin{array}{l}\text { Daya ikat air (DIA) } \\
\text { (water-holding capacity } \\
(W H C) \text { ) }\end{array}$} & $0,0+0,0(\mathrm{P} 0)$ & 22,96 & 21,63 & 18,70 & 21,03 \\
\hline & $0,5+1,0(\mathrm{P} 1)$ & 23,46 & 22,88 & 17,30 & 21,21 \\
\hline & $0,1+2,0(P 2)$ & 22,90 & 21,80 & 18,32 & 21,07 \\
\hline & $1,5+3,0(P 3)$ & 23,80 & 22,78 & 19,93 & 22,17 \\
\hline Rerata (average) & & $23,28^{a}$ & $22,27^{a}$ & $18,56^{b}$ & \\
\hline
\end{tabular}


waktu 16 jam. Hidrolisis enzim protease dipengaruhi oleh waktu dan konsentrasi. Penambahan enzim pada konsentrasi tertentu membutuhkan waktu untuk inkubasi tertentu (Utami et al., 2011). Aktivitas enzim optimum bila konsentrasi enzim tinggi dengan waktu inkubasi yang tepat.

Daya ikat air (DIA). Konsentrasi tepung kunyit dan tepung jahe sampai aras P3 tidak berpengaruh nyata terhadap daya ikat air. Hal ini diduga kandungan enzim protease dan fenol sampai aras penambahan tertinggi belum mampu mempengaruhi daya ikat air. Afrila dan Santoso (2012) menyatakan bahwa peningkatan daya ikat air disebabkan oleh adanya enzim proteolitik pada jahe (zingibain) yang bekerja melonggarkan mikrostruktur daging. Enzim proteolitik merusak membran otot sehingga terjadi difusi ion ke dalam protein daging. Jika terjadi difusi ion ke dalam protein daging maka akan terjadi pergantian ion divalensi dengan ion monovalen pada rantai protein. Akibatnya pergantian kation divalen maka ion monovalen protein akan dapat mengikat air (Soeparno, 2005). Pada penelitian ini diduga enzim proteolitik dalam jahe belum dapat bekerja maksimal sehingga tidak menyebabkan perubahan mikrostruktur daging, dengan demikian tidak menyebabkan perbedaan daya ikat air. Selain itu, senyawa fenol pada kunyit dan jahe yang tidak terserap sempurna ke dalam daging diduga menyebabkan daya ikat air tidak mengalami perubahan dengan penambahan tepung kunyit dan tepung jahe. Wulandari (2012) menyatakan bahwa senyawa fenol mampu mengikat gugus aldehid, keton asam, dan ester yang dapat mempengaruhi kemampuan mengikat air pada daging.

Hasil penelitian menunjukkan daya ikat air bakso itik afkir dengan waktu penyimpanan 0 , 8, dan 16 jam berbeda nyata $(P<0,05)$. Kemampuan daya ikat air menurun pada waktu penyimpanan 16 jam. Penurunan daya ikat air selama penyimpanan terjadi karena perubahan struktur protein dan pada penelitian yang tampak nyata pada 16 jam. Utami et al. (2011) menyatakan bahwa perubahan daya ikat air karena adanya solubilitas protein daging dan solubilitas protein terganggu dengan adanya denaturasi protein. Dewi (2012) menyatakan bahwa komponen utama yang berfungsi menahan air daging adalah proteindan degradasi kolagen dari protein yang menyusun ikatan silang di antara serat daging dapat mempengaruhi daya menahan air tersebut. Perubahan struktur protein dalam daging seiring dengan lama waktu penyimpanan dapat melemahkan kemampuan daging untuk mengikat cairannya.

Interaksi antara lama waktu penyimpanan dan penambahan tepung kunyit dan tepung jahe tidak berpengaruh nyata terhadap daya ikat air bakso itik afkir. Konsentrasi penambahan tepung kunyit dan jahe dengan bertambahnya waktu tidak dapat mempertahankan daya ikat air. Hal ini diduga kandungan minyak atsiri pada tepung kunyit dan tepung jahe mudah menguap. Almasyuri et al. (2012) menyatakan bahwa minyak atsiri termasuk unsur volatil yang mudah menguap selama waktu penyimpanan. Lama waktu penyimpanan menyebabkan minyak atsiri mengalami kejenuhan sehingga sudah tidak mampu mengikat air (Puspitasari et al., 2013). Berdasarkan hal tersebut menyebabkan kandungan minyak atsiri rendah karena menguap seiring bertambahnya waktu penyimpanan sampai 16 jam, sehingga tidak mampu mempengaruhi daya ikat air.

\section{Kualitas mikrobiologi}

Hasil penelitian penggunaan tepung kunyit dan tepung jahe dalam bakso itik afkir dengan lama penyimpanan yang berbeda terhadap kualitas mikrobia akan disajikan pada Tabel 2.

Pemberian tepung kunyit dan tepung jahe pada bakso itik afkir tidak mempengaruhi total bakteri proteolitik. Hal ini sesuai dengan penelitian Puspitasari et al. (2013) pelumuran kunyit sebagai pengawet alami tidak berpengaruh terhadap total bakteri proteolitik. Hal ini dimungkinkan perebusan pada bakso menyebabkan bakteri proteolitik mati, sehingga pertumbuhan bakteri mengalami fase awal lagi (fase lag) sehingga pertumbuhan bakterinya masih sedikit. Wati dan Prasetyani (2011) menyatakan bahwa fase adaptasi atau fase lag yaitu periode awal, pertumbuhan bakteri belum tampak karena bakteri masih dalam kondisi penyesuaian dengan lingkungannya. Kondisi tersebut memungkinkan dengan penambahan konsentrasi tepung kunyit dan tepung jahe terendah pada penelitian sudah mampu menghambat pertumbuhan bakteri proteolitik, mengingat adanya kandungan antimikrobia. Antimikrobia yang terdapat dalam tepung kunyit dan tepung jahe adalah kurkumin dan minyak atsiri. Marwati et al. (1996) menyatakan bahwa minyak atsiri dan 
Tabel 2. Rerata jumlah bakteri proteolitik (CFU/g) bakso itik afkir dengan aras penambahan tepung kunyit dan tepung jahe pada lama waktu penyimpanan yang berbeda (the mean of proteolitic bacteria number (CFU/g) in culled duck meatball with turmeric powder and ginger powder addition in different storage time)

\begin{tabular}{ccccc}
\hline \hline \multirow{2}{*}{$\begin{array}{c}\text { Konsentrasi tepung kunyit dan tepung } \\
\text { jahe (\%) (concentration of turmeric flour } \\
\text { and ginger flour (\%)) }\end{array}$} & \multicolumn{2}{c}{ Lama penyimpanan (jam) (storage time (hour)) } & \multirow{2}{*}{$\begin{array}{c}\text { Rerata } \\
\text { (average) }\end{array}$} \\
\cline { 2 - 4 } ns \\
\hline $0,0+0,0$ (P0) & 0 & 8 & 16 & \\
$0,5+1,0$ (P1) & $1,26 \times 10^{4}$ & $3,11 \times 10^{4}$ & $4,79 \times 10^{4}$ & $3,38 \times 10^{4}$ \\
$0,1+2,0$ (P2) & $1,24 \times 10^{4}$ & $2,29 \times 10^{4}$ & $3,10 \times 10^{4}$ & $2,21 \times 10^{4}$ \\
$1,5+3,0$ (P3) & $1,27 \times 10^{4}$ & $2,45 \times 10^{4}$ & $3,20 \times 10^{4}$ & $2,27 \times 10^{4}$ \\
Rerata (average) & $1,50 \times 10^{4}$ & $2,55 \times 10^{4}$ & $3,57 \times 10^{4}$ & $2,29 \times 10^{4}$ \\
\hline
\end{tabular}

ns berbeda tidak nyata (non significant).

komponen terpenoid yang ada di dalamnya dapat merusak membran biologis sel atau asosiasi protein enzim sehingga bakteri mengalami lisis dan terhambat pertumbuhannya. Kurkumin merupakan senyawa fenolik yang akan merubah permeabilitas membran sitoplasma yang menyebabkan kebocoran nutrien, sehingga sel akan mati atau terhambat pertumbuhannya. Irianto (2006) menyatakan bahwa pertumbuhan bakteri dipengaruhi oleh jumlah senyawa penghambat dan bakteri yang akan dihambat.

Penambahan tepung kunyit dan tepung jahe pada penelitian ini dimungkinkan sampai dengan aras P3 telah mampu menghambat pertumbuhan bakteri, karena jumlah bakteri masih sedikit, sehingga bakteri mengalami pertumbuhan yang lambat dan tidak terjadi peningkatan yang signifikan. Standar Nasional Indonesia (1995) menjelaskan tentang jumlah maksimal total mikrobia pada bakso $1 \times 10^{5} \mathrm{koloni} / \mathrm{g}$, pada penelitian koloni tertinggi $4,76 \times 10^{4}$, sehingga bakso masih cukup layak dikonsumsi. Hal ini sesuai dengan Hadittama (2009) bakso tidak layak dikonsumsi setelah lebih dari 24 jam.

Berdasarkan hasil penelitian lama waktu penyimpanan tidak berpengaruh nyata terhadap total bakteri proteolitik bakso itik afkir. Lama penyimpanan hingga 16 jam tidak menunjukkan peningkatan ataupun penurunan bakteri proteolitik. Hal ini dikarenakan metode pemasakan bakso dengan cara direbus pada suhu $60-70^{\circ} \mathrm{C}$ menyebabkan bakteri mati sehingga melalui tahap awal pertumbuhan lagi (fase lag). Laju pertumbuhan yang sama pada bakteri proteolitik tersebut menyebabkan tidak terjadinya perbedaan pertumbuhan bakteri. Hal ini sesuai dengan penelitian Raharjo dan Santosa (2005) yang menyatakan bahwa pemanasan pada suhu $58-75^{\circ} \mathrm{C}$ sudah dapat membunuh sebagian bakteri dan menekan pertumbuhan bakteri. Perebusan pada bakso dapat me- reduksi jumlah awal mikrobia (Hadditama, 2009). Fase lag merupakan periode awal adaptasi mikrobia, pada periode ini tidak ada peningkatan jumlah bakteri atau pertumbuhannya tetap sama atau sedikit sekali terjadi perkembangan populasi meskipun metabolisme sel terus berlangsung (Fauziah et al., 2013).

Hasil analisis total bakteri proteolitik menunjukkan bahwa tidak ada interaksi antara penambahan tepung kunyit dan tepung jahe dengan waktu penyimpanan. Hasil penelitian menunjukkan hingga konsentrasi P3 belum mampu menghambat pertumbuhan bakteri proteolitik pada bakso itik seiring bertambahnya waktu penyimpanan. Hal ini diduga kandungan kurkumin dan minyak atsiri pada tepung kunyit dan jahe P3 sebagai senyawa antimikrobia kurang efektif menghambat pertumbuhan bakteri dengan bertambahnya waktu penyimpanan karena menguap. Hal ini sesuai pendapat Puspitasari (2008) yang menyatakan bahwa lama penyimpanan menyebabkan senyawa antimikrobia menguap sehingga keefektifan senyawa berkurang. Minyak atsiri atau minyak eteris (essential oil, volatile oil, etherial oil) adalah minyak mudah menguap yang diperoleh dari tanaman (Ketaren, 1987). Kandungan senyawa volatil bertanggung jawab terhadap efek antimikrobia dan senyawa volatil pada minyak atsiri dapat menguap selama proses penyimpanan (Antara, 2013).

\section{Kesimpulan}

Aras penambahan yang terbaik adalah $0,5 \%$ tepung kunyit dan $1 \%$ tepung jahe dengan lama penyimpanan 0 jam karena dengan pemberian tepung kunyit dan tepung jahe belum bermanfaat terhadap bakso itik afkir. 


\section{Daftar Pustaka}

Afrila, A. dan B. Santoso. 2012. Water-holding capacity (WHC), kadar protein, kadar air dendeng sapi pada berbagai konsentrasi ekstrak jahe (Zingiber officinale Roscoe) dan lama perendaman yang berbeda. Jurnal IImu dan Teknologi Hasil Ternak 6: 41-46.

Almasyuri, S. Wardatun, dan L. Nuraeni. 2012. Perbedaan cara pengirisan dan pengeringan terhadap kandungan minyak atsiri dalam jahe merah (Zingeber officinale Roscoe. Sunti Valeton). Buletin Penelitian Kesehatan 40: 123-129.

Anggraeni, Y. 2005. Sifat fisik daging dada ayam broiler pada berbagai lama postmortem di suhu ruang. Skripsi Fakultas Peternakan, Institut Pertanian Bogor, Bogor.

Antara, N. S. 2013. Senyawa Aroma dan Citarasa. http://seafast.ipb.ac.id. Diakses pada 23 Juli 2014.

AOAC. 1995. Official Methods of Analysis of The Association of Official Agricultural Chemists, Washington D.C.

Ariansah. 2008. Sifat fisik dan organoleptik bakso daging itik dengan dan tanpa kulit dengan penambahan daun belutas (Pulchea indica L.) dalam Pakan. Skripsi Jurusan Teknologi Hasil Ternak, Institut Pertanian Bogor, Bogor.

Baygar, T., N. Erkan, S. Mol, O. Ozden, D. Üçok and Y. Yildirim. 2008. Determination of the shelf-life of trout (Oncorrhynchus mykiss) raw meatball that packed under modified atmosphere. Pakistan Journal of Nutrition 7: 412-417.

Dewi, S. H. C. 2012. Populasi mikroba dan sifat fisik daging sapi beku pada lama penyimpanan yang berbeda. Jurnal Agrisains 3: 1-12.

Elmali, M. and H. Yaman. 2005. Microbiological quality of raw meat balls: produced and sold in the eastern of Turkey. Pakistan Journal of Nutrition 4: $197-201$

Fardiaz, S. 1993. Mikrobiologi Pengolahan Pangan Lanjut. Penerbit Institut Pertanian Bogor, Bogor.
Fauziah, P. N. J. Nurhayati, dan Chrysanti. 2013. Pengaruh laju pertumbuhan dan waktu generasi terhadap penghambatan pertumbuhan koloni Klebsiella pneumoniae strain ATCC 700603, CT1538 dan S941 oleh Lactobacillus bulgaricus KS1 dalam soyghurt. E-Journal Sekolah Tinggi Ilmu Kesehatan Achmad Yani Cimahi. http://www.stikesayani.ac.id. Diakses pada 2 Agustus 2014.

Hadittama. 2009. Studi penggunaan ekstrak bawang putih (Allium sativumLinn) pada pengawetan bakso dengan asam asetat. Skripsi Fakultas Teknologi Pertanian, Institut Pertanian Bogor, Bogor.

Herdyastuti, N. 2006. Isolasi dan karakterisasi ekstrak kasar enzim bromelin dari batang nanas (Ananas comusus L.merr). Jurnal Penelitian Hayati 12: 75-77.

Irianto, K. 2006. Mikrobiologi: Menguak Dunia Mikroorganisme. Penerbit Yrama Widya, Bandung.

Ketaren, S. 1987. Minyak Atsiri. Penerbit Universitas Indonesia, Jakarta.

Komariah, N. Ulupi, dan Y. Fatrani. 2004. Pengaruh penambahan tepung tapioka dan es batu pada berbagai tingkat yang berbeda terhadap kualitas fisik bakso sapi. Buletin Peternakan 28: 80-86.

Marwati, T., C. Winarti, dan D. Sumangat. 1996. Aktivitas zat antibakteri pada rimpang kunyit. Dalam: Prosiding Simposium Nasional: Tumbuhan Obat dan Aromatik APIMAP: 37-43.

Naufalin, R., B. S. L. Jenie, F. Kusnandar, M. Sudarwanto, dan H. S. Rukmini. 2006. Pengaruh $\mathrm{pH}, \mathrm{NaCl}$ dan pemanasan terhadap stabilitas antibakteri bunga kecombrang dan aplikasinya pada daging sapi giling. Jurnal Teknologi dan Industri Pangan 17: 197-203.

Ockerman, H. W. 1983. Chemistry of Meat Tissue. $10^{\text {th }}$ edn. Departement of Animal Science. The Ohio State University and The Ohio Agriculture Research and Development Center, Ohio.

Purnomo, H. and D. Rahardiyan. 2008. Review Article: Indonesian traditional meatball. International Food Research Journal 15: 101-108. 
Purwani, E., Y. D. Susanti, D. P. Ningrum, Widati, dan Q. Quyyimah. 2012. Karakteristik daya hambat pertumbuhan bakteri perusak hasil isolasi dari ikan nila (Oreochromis niloticus) oleh ekstrak jahe (Zingiber officinale) dengan pengencer emulsi Tween 80 . Jurnal Kesehatan 5: 45-55.

Puspitasari, D. 2008. Kajian subtitusi tapioka dengan rumput laut (Eucheuma cottoni) pada pembuatan bakso. Skripsi Fakultas Pertanian, Universitas Sebelas Maret, Surakarta.

Puspitasari, I., A. M. P. Nuhriawangsa, dan W. Swastike. 2013. Pengaruh pemanfaatan kunyit (Curcuma domestica Val.) terhadap kualitas mikrobia dan fisiko-kimia daging sapi. Tropical Animal Husbandry 2: 158-64.

Putri, M. P., Wignyanto, dan N. Mayang. 2013. Hasil ekstraksi daun sirih hijau (Piperbetle L.) sebagai pengawet alami pada bakso sapi. http://industria. lecture.ub.ac.id. Diakses pada 30 April 2014.

Rahardjo, M. dan O. Rostiana, 2005. Budidaya Tanaman Kunyit. Sirkuler no. 11. Balai Penelitian Tanaman Obat dan Aromatika. Badan Litbang Pertanian, Departemen Pertanian, Bogor.

Raharjo, A. H. D. dan B. S. Santosa. 2005. Kajian terhadap kualitas karkas broiler yang disimpan pada suhu kamar setelah perlakuan pengukusan. Jurnal Produksi Ternak 7: 1-5.

Rakhmadi, A., D. Novia, dan D. Rena. 2009. Karakteristik bakso itik afkir dengan subtitusi beberapa jenis tepung dengan jumlah yang berbeda. Skripsi Fakultas Peternakan, Universitas Andalas, Padang.

Risnajati, D. 2010. Pengaruh lama penyimpanan dalam lemari es terhadap $\mathrm{pH}$, daya ikat air, dan susut masak karkas broiler yang dikemas plastik polyethylen. Jurnal IImiah ilmu Peternakan 6: 309-315.
Sari. 2009. Kunyit sebagai alternatif bahan pengawet alami. Skripsi Jurusan Teknologi Industri Pertanian, Fakultas Teknologi Pertanian, Universitas Udayana, Bali.

Soeparno. 2005. Ilmu dan Teknologi Daging. Edisi IV. Penerbit Universitas Gajah Mada, Yogyakarta.

Standar Nasional Indonesia No. 01-3818. 1995. Bakso Daging. Badan Standarisasi Nasional, Jakarta.

Steel, R. G. D. and J. H. Torrie. 1995. Principles and Procedures of Statistics: A Biometry Approach. Penerjemah: B. Sumantri. Penerbit PT. Gramedia Pustaka Utama, Jakarta.

Utami, D. P., Pudjomartatmo, dan A. M. P. Nuhriawangsa. 2011. Manfaat bromelin dari ekstrak buah nanas (Ananas comosus L. Merr) dan waktu pemasakan untuk meningkatkan kualitas daging itik afkir. Jurnal Sains Peternakan 9: 82-87.

Wati, D. S. dan R. D. Prasetyani. 2011. Pembuatan biogas dari limbah cair industri bioetanol melalui proses anaerob (fermentasi). Laporan Penelitian, Progam Studi Teknik Kimia, Fakultas Teknik, Universitas Diponegoro, Semarang.

Wulandari, S. 2012. Pengaruh jenis otot dan level asap cair terhadap kualitas daging pascarigor sapi Bali. Skripsi Jurusan Produksi Ternak, Fakultas Peternakan, Universitas Hasanuddin, Makassar.

Yadnya, T. G. B., N. M. S. Sukmawati, A. A. A. S. Trisnadewi, dan A. A. P. P. Wibawa. 2010. Pengaruh pemberian jahe (Zingiber officinale Rosc.) dalam ransum terhadap penampilan itik petelur afkir. Jurnal IImu dan Teknologi Hasil Ternak 5: 41-48. 